\title{
義歯安定剤の最近の見解と患者指導
}

Recent information and patient education regarding denture stabilizers

村田 比呂司

Hiroshi Murata

Keyword : denture stabilizer, denture adhesive, home reliner, denture maintenance

キーワード: 義歯安定剤, 義歯粘着剂, ホームリライナー, 義歯管理

Denture stabilizers are available on the retail market and often used by denture wearers to improve the function of an ill-fitting denture. They can be broadly divided into denture adhesives, available in cream, powder, and sheet (tape) forms, and home reliners, which are in cushion form. Although denture stabilizers were initially considered to have negligible effects, the usefulness of denture adhesives has been increasingly recognized by researchers in recent years. In those studies, cream and powder types have been shown to be useful adjuncts for denture maintenance and denture prosthesis applications when used in a correct manner under suitable conditions. However, harmful effects caused by improper use are often found in patients. Therefore, it is important for dentists to acquire proper knowledge regarding denture adhesives and their correct application in order to take advantage of the materials and prevent incorrect use.

義歯安定剂は維持，安定の不良な義歯の機能改善を目的として患者自身によって用いられる市販材料である，本 片は義歯床を義歯床下粘膜に固定する方法により，義歯粘着棛 [クリーム夕イプ，粉末タイプ，シート（テープ） タイプ］とホームリライナー(クッションタイプ) に分類される．従来より義歯安定剤に対する見解は否定的であっ たが，近年，その有用性が種々の研究より報告されている，義歯安定郕のうち，クリームタイプや粉末夕イプの義 歯粘着剤は，適切な症例に正しく使用すれば，義歯管理や補緅歯科治療に有用な補助的材料であると認識されるよ うになった。しかしながら，患者の誤使用による弊害も見受けられ，義歯安定剤（義歯粘着剤）の効果を十分に発 揮させ，また䛊使用を防ぐためには，歯科医師が正しい知識をもち，患者に正しい使用法を教育していくことが重 要である.【顎咬合誌 38(3) :155-165, 2018】

はじめに

義歯安定剤は維持，安定の不良な義歯の機能改善を目 的として患者自身によって用いられる市販材料と定義さ れている ${ }^{1)}$ 。義歯安定剂に関して多くの歯科医師は，義 歯が正しく製作されていれば本剤は不要で，術者の補綴 治療技術が未熟であるため患者が使用するという見解が

長崎大学大学院 医歯薬学総合研究科 歯科補綴学分野

₹ 852-8588＼cjkstart長崎県長崎市坂本 1-7-1

受付日：2018 年 5 月 28 日
大多数を占めていたし，現在もそうであろう。しかしな がら, 近年欧米を中心に義歯安定剤の有用性が報告され, 本剤に対する見解も変化しつつある.

義歯安定剤に対する見解の変化は, 義歯を取り巻く環 境の変化も大きな要因になっていると思われる. 8020 運動の効果により義歯装着者の割合は減っているよう であるが，いまだ多くの高齢者が義歯を装着している (図 1）2）。た口腔内の環境については，以前よりも 義歯の装着にとって不利な顎堤をもつ高齢者が増加して いるように感じる，全部床義歯の学生実習に用いるよう な骨吸収の少ない顎堤は少なく，多くは高度に骨吸収し， 
粘膜が菲薄である症例，いわゆる難症例が増えている. さらに加齢あるいは服用している薬により口腔乾燥を有 する患者も多く，快適な義歯の装着をますます困難にし ている.このような状況下, 義歯安定剤は適切な症例に 正しく使用すれば，義歯管理や補綴歯科治療に有用な補 助的材料との認識がなされるようになった。本稿では義 歯安定剂の基本的な事項, 現時点での見解ならびに正し い使い方と患者指導について解説させていただく.

\section{義歯安定剤の種類, 成分および作用機序}

義歯安定剤は義歯床を床下粘膜に固定する方法に より，義歯粘着剤とホームリライナーに分類される （図 2）1，3，4）。義歯粘着剤はクリームタイプ, 粉末夕
イプおよびシート（テープ）タイプの剂形がある。ホ ームリライナーはクッションタイプのみである（図 3). JIS 規格では, 義歯粘着剤を粘着型義歯床安定用こ（糊） 材，ホームリライナーを密着型義歯床安定用こ（糊）材 とそれぞれ呼称している5)。現在, 市販されている主な 義歯粘着剤を表 1 に示す.

\section{1）義歯粘着剂}

クリームタイプや粉末タイプの義歯粘着剤は義歯床粘 膜面と床下粘膜の間で唾液などを吸収して粘着性を発揮 させることにより, 義歯の維持, 安定を向上させる（粘 着作用） ${ }^{6)}$ 。本剂は流動性が高く, 義歯床に薄く均一に 広がるため, 咬合高径の変化や咬合のずれが生じにくい 性質を有している。両夕イプとも主剤は水膨潤性の水溶 性高分子化合物であり（図 4), この化合物は水を吸収,

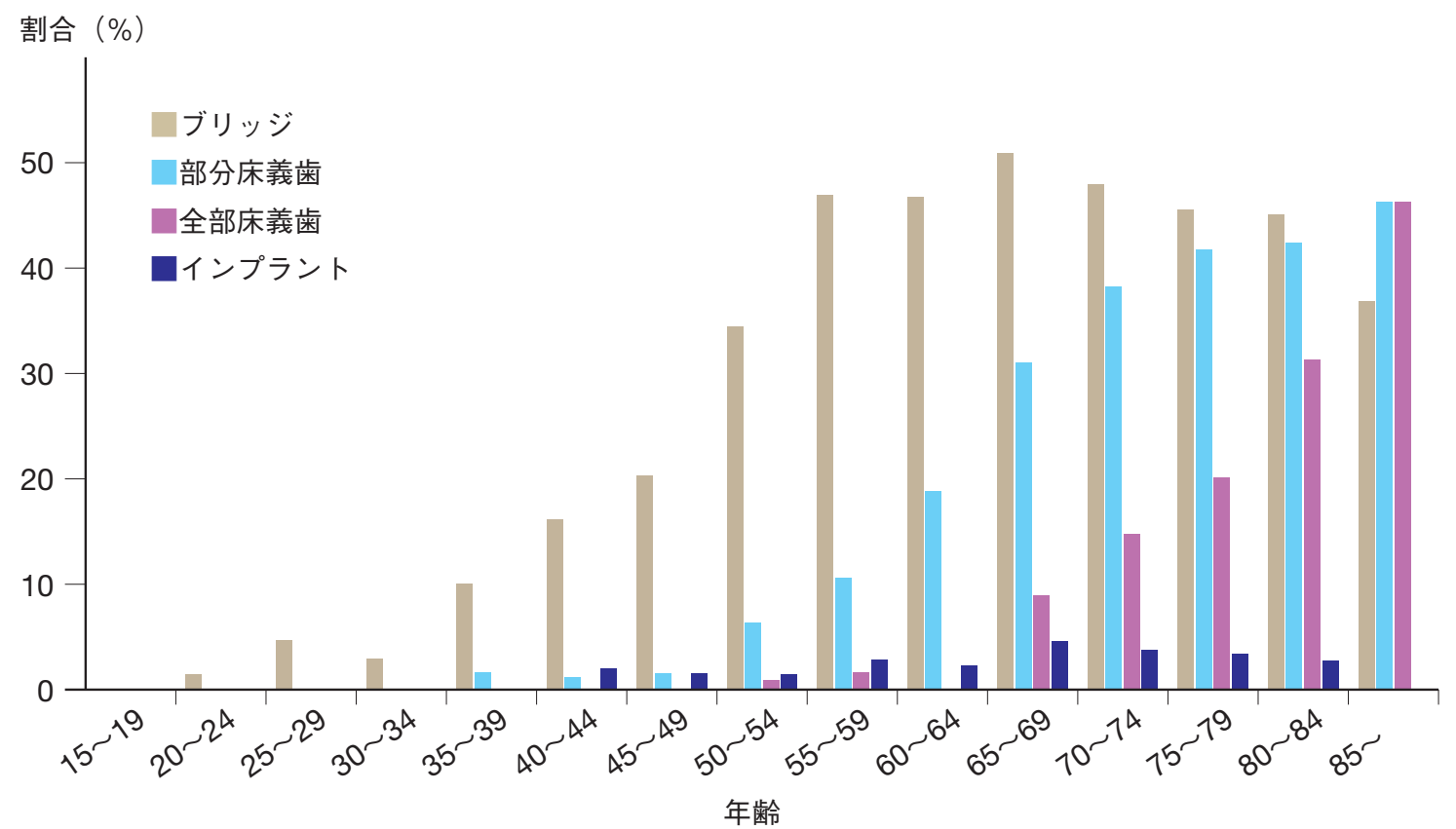

図1補緅装置を装着している者の割合（平成28年歯科疾患実態調査データーから作成）

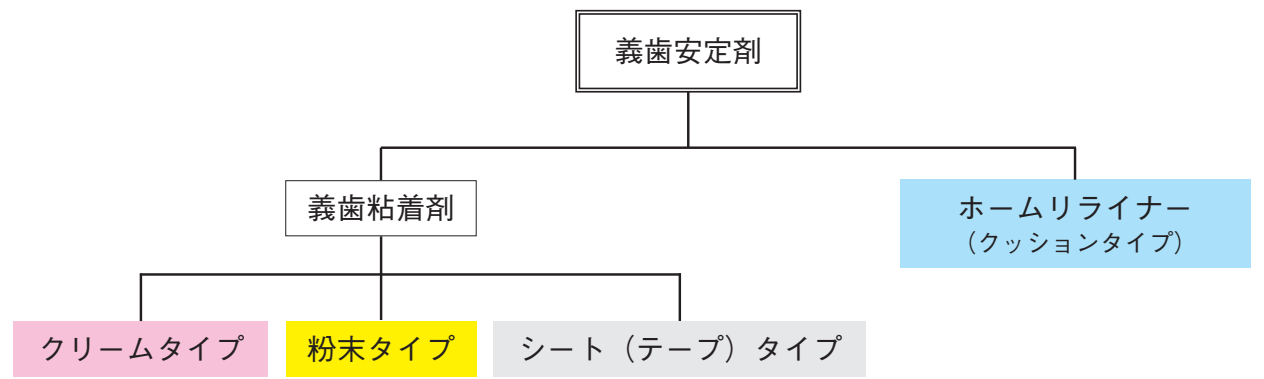

義歯安定剂の分類 


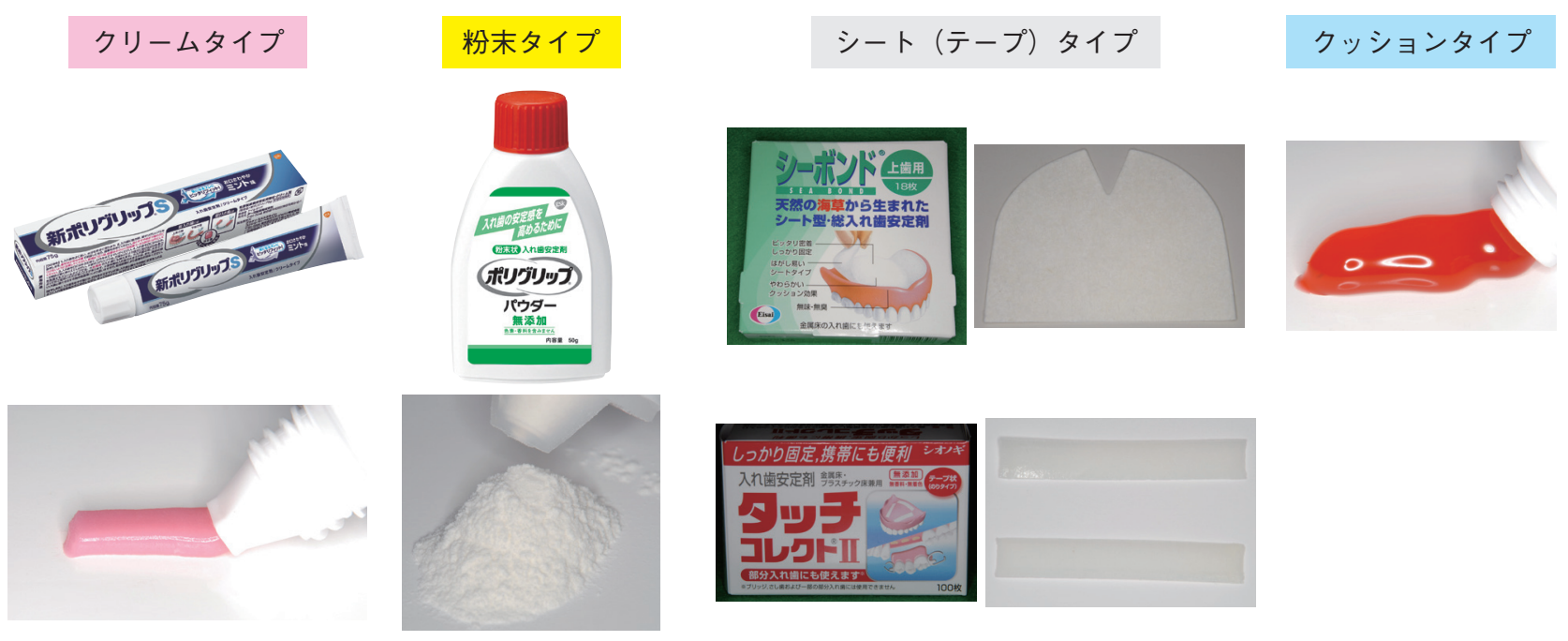

図3 市販義歯安定剤の各タイプ

現在, 市販されている義歯安定剤はこれら4種類のタイプのどれかに該当する.

このなかでもっとも大きなシェアを占めているのはクリームタイプである.

表1 市販義歯安定剂（義歯粘着剤）

\begin{tabular}{|c|c|c|}
\hline クリームタイプ & 粉末タイプ & シート（テープ） タイプ \\
\hline $\begin{array}{l}\text { 新ポリグリップ無添加 } \\
\text { 新ポリグリップS }\end{array}$ & \multirow[t]{2}{*}{$\begin{array}{l}\text { ポリグリップパウダー無添加 } \\
\text { グラクン・スミスクライン, スタッフォードミ } \\
\text { ラー (アイルランド) リミテッド, アース製薬 }\end{array}$} & \multirow[t]{2}{*}{$\begin{array}{c}\text { タッチコレクトII } \\
\text { 塩野義製薬, 共和 }\end{array}$} \\
\hline 新ポリグリップV & & \\
\hline $\begin{array}{l}\text { 新ポリグリップトータルプロテクション } \\
\text { グラクン・スミスクライン, スタッフォードミ } \\
\text { ラー (アイルランド) リミテッド, アース製薬 }\end{array}$ & \multirow[t]{2}{*}{$\begin{array}{l}\text { ポリグリップパウダー無添加 歯科用 } \\
\text { グラクソ・スミスクライン, スタッフォードミ } \\
\text { ラー (アイルランド) リミテッド, ジーシー }\end{array}$} & \multirow[t]{3}{*}{$\begin{array}{l}\text { シーボンド } \\
\text { 光洋産業, コーム ラボラトリーズ インコーポ } \\
\text { レイテッド, エーザイ }\end{array}$} \\
\hline $\begin{array}{l}\text { 歯科用 新ポリグリップ無添加 } \\
\text { グラクソ・スミスクライン, スタッフォードミ } \\
\text { ラー (アイルランド) リミテッド, ジーシー }\end{array}$ & & \\
\hline $\begin{array}{l}\text { コレクトXYLクリーム } \\
\text { 塩野義製薬, 日本ゼトック }\end{array}$ & $\begin{array}{l}\text { 新ファストン } \\
\text { ライオン }\end{array}$ & \\
\hline
\end{tabular}

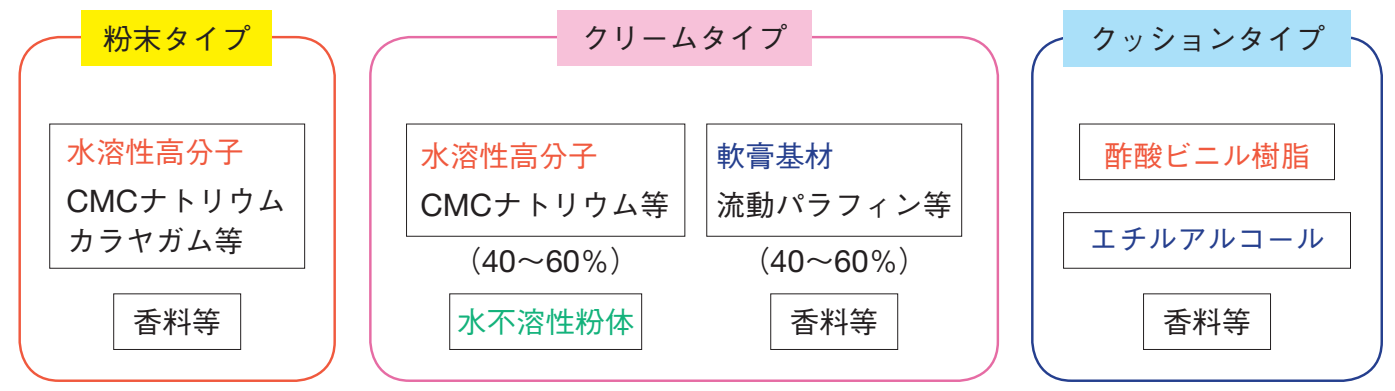

図4 義歯安定剤の成分 
膨潤して高粘度の粘液となる。粉末タイプではカルボキ シメチルセルロースナトリウムなどの半合成高分子, カ ラヤガム，アラビアガムなどの高粘着性物質である植物 性ガムなどが用いられている4，6，7)。義歯床に塗布後, 水および唾液を吸収しゲル状になり，粘着性を示す。ク リームタイプの基本組成も粉末タイプと同じで, カルボ キシメチルセルロースナトリウムやメトキシエチレン無 水マレイン酸共重合体などを主成分としている，剤形を クリーム状にするため, 白色ワセリンや流動パラフィン などの軟膏基材が含有されている 4, 6, 7). シート（テ ープ）タイプはやや硬めのシートや紙，不織布にカルボ キシメチルセルロースナトリウムやアルギン酸ナトリウ ムなどの成分が含浸されている 4, 6, 7).

2) ホームリライナー

ホームリライナーは義歯床粘膜面と床下粘膜間の間 隙を埋めて固定させるものである（密着作用） ${ }^{6)}$ ，本郕 は非水溶性であり，酢酸ビニル樹脂を主成分とし，ほ とんどの製品でエチルアルコールが含有されている （図 4）4，6，7）、ペーストの粘度が高いため，義歯床全 面に均質に広がりにくく，不適切な咬合関係や義歯床と 床下粘膜間に不適合を引き起こす可能性がある。さらに 含有されているエチルアルコールが比較的早い時期に口 腔内に溶出するため, 初期の物性を失いやすい。そのた め現時点ではクッションタイプはあまり推奨できないと されている1).

\section{義歯安定剂の現在の見解}

義歯安定剤の見解に関して重要な論文を取り上げ，本 剤の現時点での見解を概説する。

\section{1）米国の大学に所属する補緅歯科専門医の見解}

冒頭でも述べたように，多くの歯科医師は義歯安定 剂に対しては否定的見解であった。しかしながら，本 邦で本剤について真剣に考えるきっかけとなった一つ に, 1999 年, The Journal of Prosthetic Dentistry に発表 された "Professional attitudes toward denture adhesives: A Delphi Technique survey of academic prosthodontists” と いう論文 ${ }^{8)}$ の発表がある。本論文は Delphi Technique という方法により，米国の全部床義歯教育に携わる 17 大学の補綴歯科専門医から義歯粘着剂についてのコンセ ンサスを得ることを目的とした調査を報告したものであ
る. なお本研究で対象としているのは義歯安定剤のうち クリームタイプなどの義歯粘着剤で, クッションタイプ の義歯安定剤（ホームリライナー）は対象としていない. 調査内容は「義歯粘着剤に対する認識」,「効果的臨床応 用と誤用」,「患者教育」,「学部学生のカリキュラム」,「総 合的意見」で, 全 24 項目の質問である。その結果（図 5), 義歯粘着剤は義歯の適合性を向上させる, 解剖学的形態 が不十分である顎堤をもつ患者の義歯の維持, 安定に有 効である, 患者に心理的安心感を与えるなど, 本剤に対 して肯定的見解が認められた。また診療室においては， ろう義歯試適や咬合採得時の咬合床の維持, 安定などに 有用であるとの見解も示された。しかしながら，歯科医 師に対して根本的な義歯の問題を隠し，患者に対しては 必要な歯科医院への来院を妨げる，という否定的な見解 もあった，たとえば，本来ならリラインで対処すべき症 例であるにもかかわらず，患者が義歯安定剤に依存して 来院せず，歯科医院での義歯管理がなおざりにされるこ となどがある，さらに義歯安定剤の誤使用により，義歯 性口内炎やカンジダ症, 顎堤の骨吸収の進行に影響を与 える可能性があることも指摘している。

義歯安定剤のうち義歯粘着剤は義歯製作および装着後 の過程において明確な役割を担っており, 補経臨床に有 用な補助的材料であると結論している．また本剤の有益 性を最大限引き出し，また誤用を最小限にするためには， 歯科医師，学生，患者に対する教育も必須であると述べ ている ${ }^{8,9)}$.

\section{2）日本補綴歯科学会の見解}

義歯安定剤の有用性や弊害に関しては臨床研究の実施 など，さらなるエビデンスが必要であるが，現時点での 日本補綴歯科学会の見解 1) は以下の通りである。すな わち, 「義歯安定剤は, 大別してホームリライナーと義 歯粘着剤とに分類できる。ホームリライナーは維持力の 向上は認められても，むしろ為害作用が大きい場合のほ うが多く, 推奨できない. 義歯粘着剤に関しては, 一定 の条件下での使用であれば容認できる。 その条件とは, 歯科医師の管理下で実施すべきであり，義歯の新規製作 を前提とした, 現有義歯の修理（粘膜調整, 床裏装, 改 床など）時における短期間の使用に限るべきである」と 提示している.

\section{3）米国の歯科医師会の見解}

2011 年, アメリカの歯科医師会雑誌（The Journal of the American Dental Association) に “Evidence-based 
guidelines for the care and maintenance of complete dentures: A publication of the American College of Prosthodontists“という論文 10）が発表された。本論文で も義歯の維持, 安定性向上の観点から義歯安定剤（義歯 粘着剤）が有用であることや本剤の正しい使い方，使用 上の注意点などが記載されている。一方で, 義歯安定剤 （義歯粘着剤）が咀嚼機能に及ぼす効果については，さ らなるエビデンスが必要であるとも述べている，なお本 論文でも対象としているのは，クリームタイプなどの義 歯粘着剤であり，クッションタイプの義歯安定剂（ホー ムリライナー）は対象外である.

\section{義歯安定剤の性質}

\section{1）安全性}

義歯安定剂は薬機法（医薬品, 医療機器等の品質, 有 効性及び安全性の確保等に関する法律）では，管理医 療機器（クラス II）に分類されている. 本剤の生物学的 安全性は ISO 規格 11）や JIS 規格 5)で評価されている. $\mathrm{pH}$ についてもこれらの規格で 4 〜 10 でなければなら
ないとされている5,11)。これは酸性の強い材料が残存 歯や口腔粘膜に長期間接すると, 歯には脱灰などの危険 性を, 粘膜には灼熱感を与える可能性があるため, 酸性 に傾かないよう規定されている．ISO 規格と測定方法は 異なるが，市販製品の $\mathrm{pH}$ を測定した報告 12) では，す べての製品で 5 以上で，もっとも低いもの（カラヤガム を成分とする製品）でも5.35 であった（図 6).

2）クリームタイプおよび粉末タイプ義歯安定剂（義 歯粘着剂）の義歯床との接着性

義歯床との接着性は本剤の評価項目のもっとも重要な 因子の一つであり，この粘着性は粘度と密接に関係して いる．図 7 に示すように義歯粘着剤の粘度は製品によ りかなり違いがある 13)。一般的に粘度が高い義歯粘着 剂ほど義歯床との粘着強さが高い傾向であり，同じ夕イ プの義歯粘着剤でも製品により粘着力が異なっている (図 8) 13)。口腔湿潤剤は本来，口腔乾燥症の患者さん にその保湿効果を期待し応用されるものであるが，義歯 の維持，安定性を高める目的で本剂が使用されることも ある ${ }^{14)}$ ，粘度が低いため義歯粘着剤よりも持続性は低 いと思われるが，症例によっては有効で，義歯床や口腔
義歯粘着剂は下記の項目に影響するか

義歯の適合性の向上

大賛成

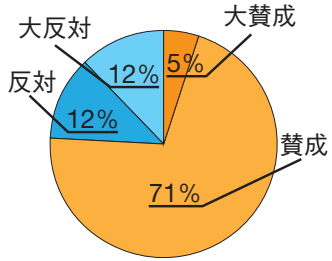
心理的安心

義歯に関する

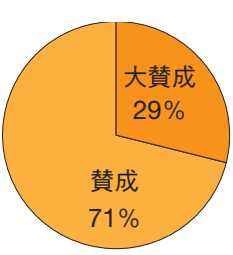
根本的問題の遮蔽

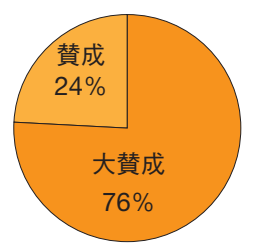
患者の義歯の維持安定

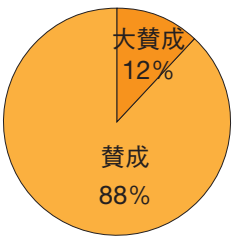

ろう義歯試適時の 患者の不安軽減

大反対

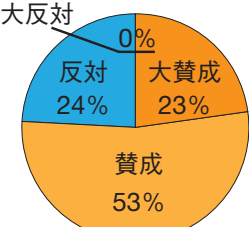

義歯粘着剤についての総合的見解

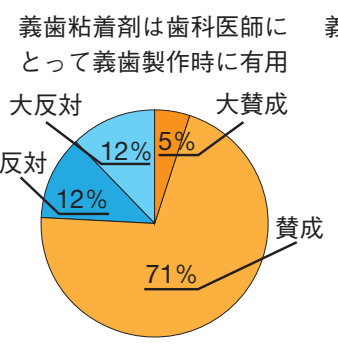

義歯粘着剤は歯科医師に

すべての義歯装着者に対する

とって患者管理に有用

義歯粘着剤の教育は必要

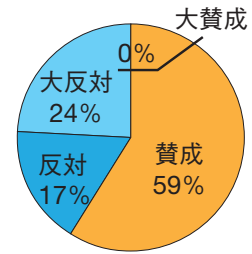

大反対

反対

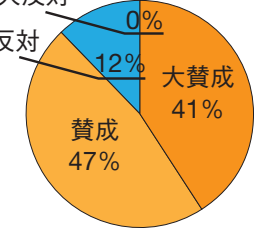

図5 米国補緅歯科専門医の義歯安定剤（義歯粘着郕）に対する考え方

注：本調査で対象としているのは義歯安定剤のうちクリームタイプなどの義歯粘着剤で,

クッションタイプ (ホームリライナー) は対象としていない. 
への残留が少ないため清掃性は良好である。なお粉末夕 イプは付着させる水の量を少なくするほど粘度が高くな るため, 義歯の維持をより強くしたい場合は, 義歯床に あまり水を付着させないよう患者に指示する．ただ実際 は患者自身が扱うため，粘着強さのばらつきはあるかと 思う。

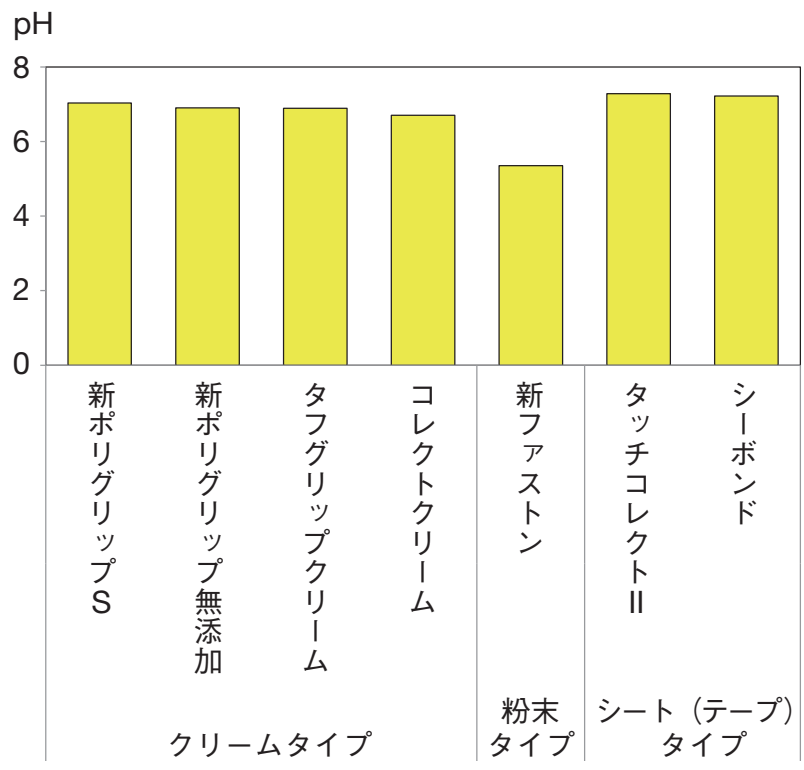

図6 義歯安定剂（義歯粘着剂）のpH

(文献12より一部データーを引用し，グラフを作成）

各材料を24時間浸漬した溶出液を測定した.
3）クッションタイプ義歯安定剤（ホームリライナー） の物性

クッションタイプ義歯安定率を触ってみると, 軟らか くクッション性があるように感じるが，咬合力が強い患 者では容易に義歯床から材料が流動し薄くなるため, 緩 圧効果が早期に失われる可能性がある。また本剤に多

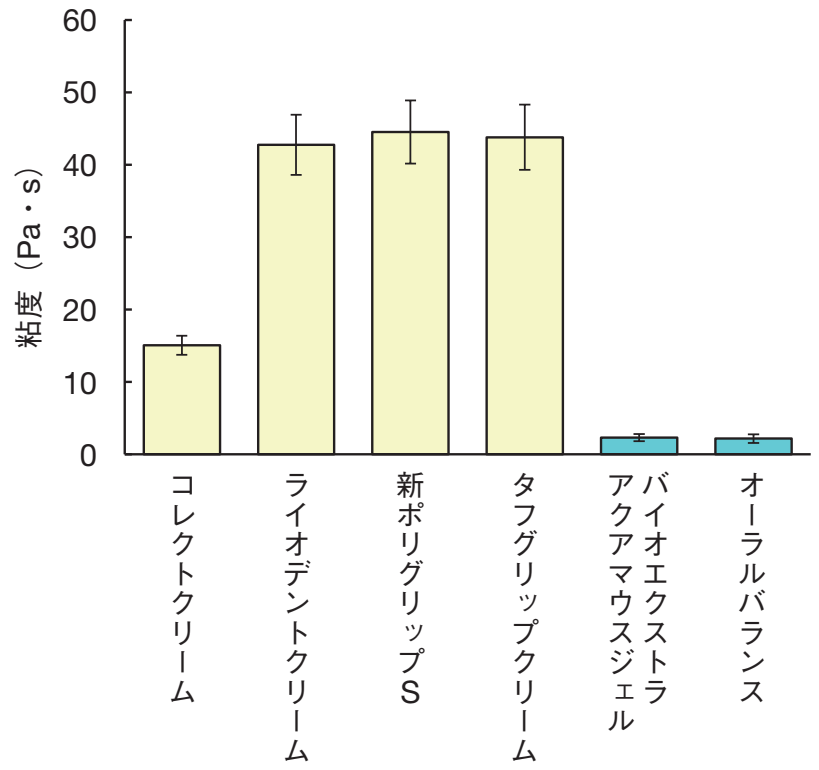

$\leftarrow$ 義歯安定剤（義歯粘着剂） $\rightarrow \leftarrow$ 口腔湿潤剤 $\rightarrow$

図7 義歯安定剤（義歯粘着剤）および口腔湿潤剤の粘度 (文献13より引用, 一部改変)

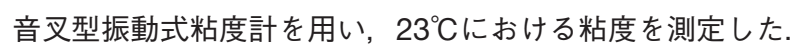

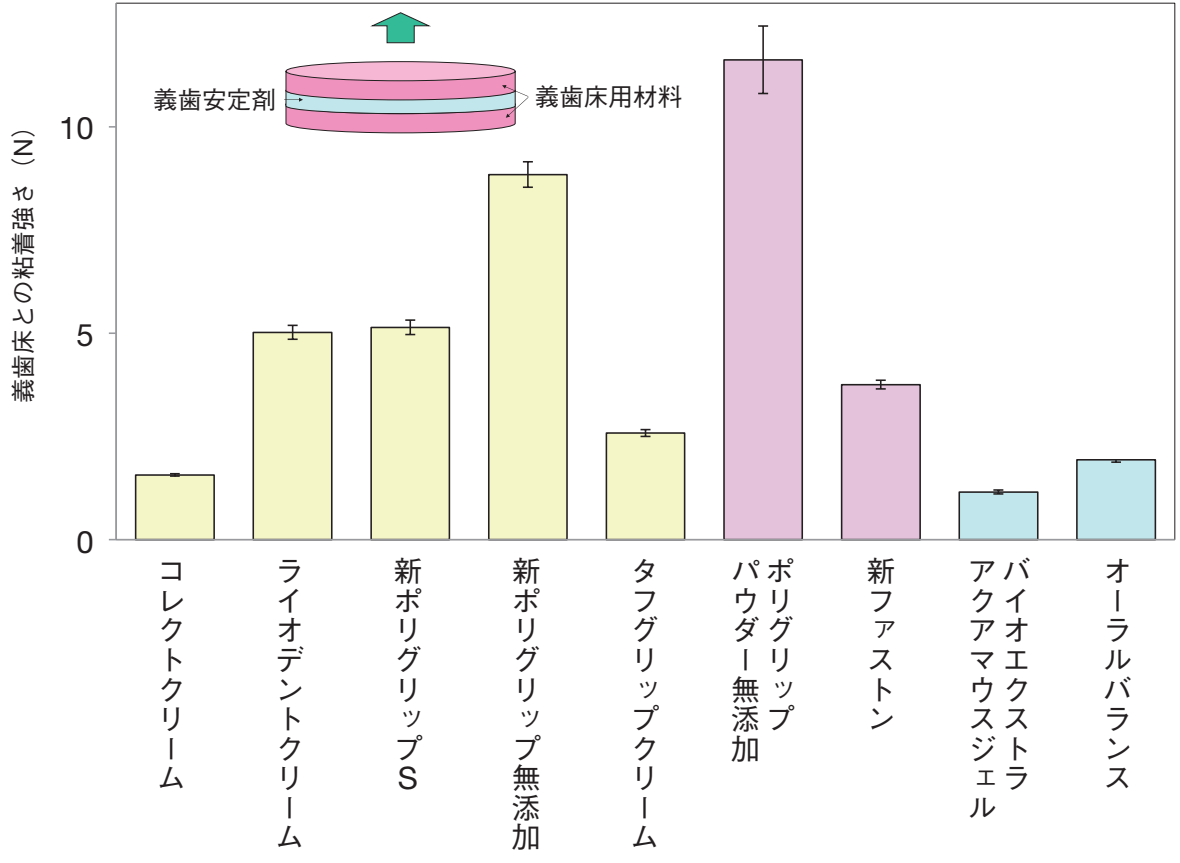

図8 義歯安定剂（義歯粘着剂） および口腔湿潤剤の義歯床との粘 着強さ

（文献13より引用，一部改変） 直径 $20 \mathrm{~mm}$ の義歯床用レジン間に 義歯安定剂（義歯粘着剤）および 口腔湿潤剤を填入し, $5 \mathrm{~mm} /$ 分で 引張を行い, 剝離時の最大荷重を 測定した（床用レジン間の間隙 〈材料の厚さ〉: $0.5 \mathrm{~mm}$ ）。粉末 タイプの粉液比は 0.25 とした. 
く含有されるエチルアルコールが口腔内へ溶出するた め, 比較的早い時期に材料が硬くなり劣化する傾向があ る（図 9）15）。水中浸漬 7 日後のアルコールなどの成分 の溶解量は $19 \sim 44 \%$, 吸水量は $48 \sim 58 \%$ と報告され ており（図 10）15）ティッシュコンディショナーなど の歯科材料に比べ溶解量, 吸水量ともに高い傾向である
義歯に塗布し長期間経過したクッションタイプは剥がし にくく，古い材料の上に新しい材料を重ねるということ も見られる。また粘度が高いため，患者が義歯床に均等 に塗布することも困難である（図 11）。そのため機能的 にも衛生的にも好ましくない状態をきたすことが多い。

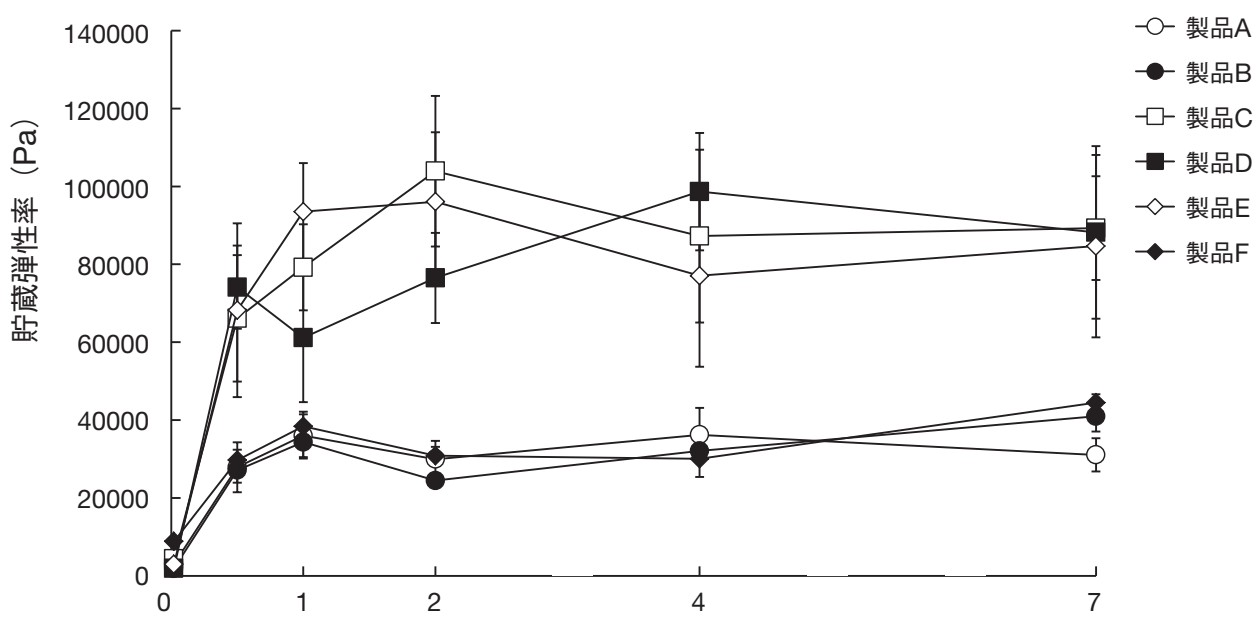

図9 クッションタイプ義歯安定剂の粘弾性值の経時的変化

(文献15より引用，一部改変)

蒸留水に浸漬保管し，37ㄷにおける貯蔵弾性率を測定した。

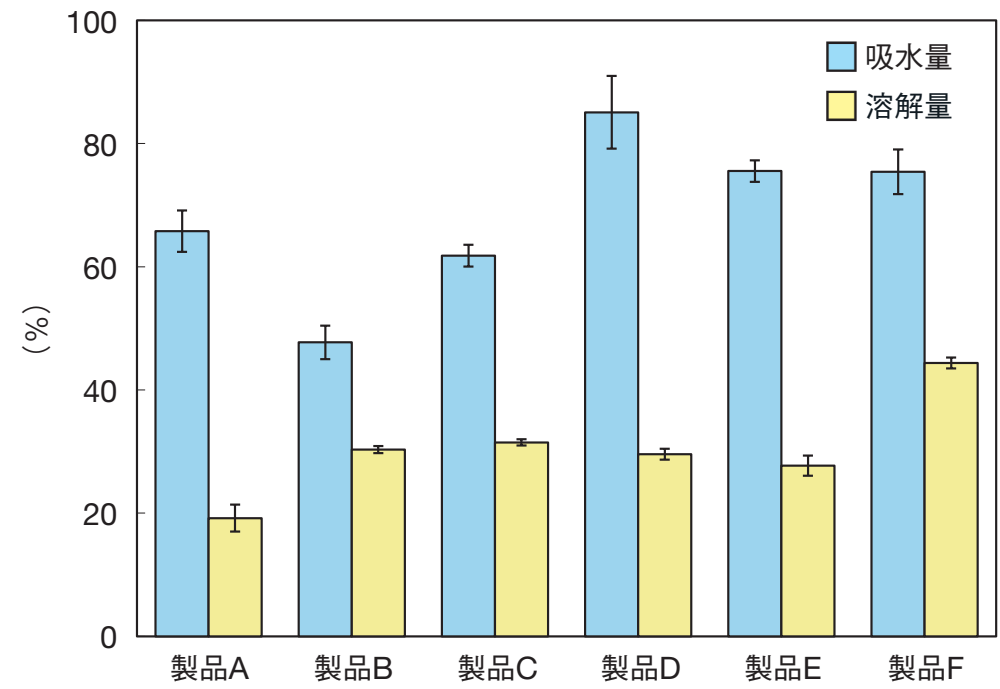

図10 クッションタイプ義歯安定剂の水中浸漬7日後の吸水量と成分の溶解量 (文献15より引用，一部改変）

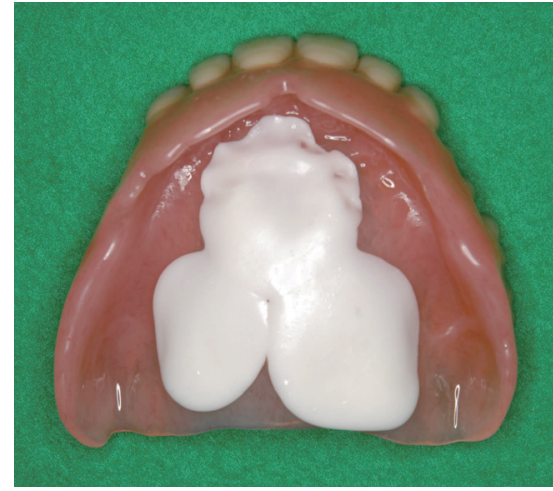

図11 不均等に塗布されたクッションタ イプ義歯安定剤 


\section{義歯安定剂（義歯粘着剂）の効果}

クリームタイプ義歯安定剤の効果について種々の報告 があり，興味深い研究を紹介する．MKG（Mandibular Kinesiograph）を用い，上顎全部床義歯の維持，安定に 及ぼす影響および incisal bite force（前歯部で咬合させ たときの咬合力）について検討した研究 16）では，本剤 の使用により不適合義歯および適合の良好な義歯ともに 咀嚼, 嚥下，会話時の維持力および安定性が向上するこ とがわかった（図 12）。早川（2007）17）も義歯安定剂 は咀嚼能力, 咬合力および維持力の向上に有用であり,
とくに不良な顎堤をもつ患者に効果的であると報告して いる.

また英国ロンドンの Guy’s Hospital で行われた研究で, 全部床義歯装着者にリーフレットによる食事指導とクリ 一ムタイプ義歯安定剤の使用により，栄養学的に適切な 食品を摂取させることができるようになったとの報告 もある 18). 30 日後で果物, 野菜の一日摂取量が, 平均 2.2 品目から 3.6 品目に増加し, 総脂肪と飽和脂肪につ いては摂取量がそれぞれ $23.2 \mathrm{~g}, 11.3 \mathrm{~g}$ 減少, さらにビ タミン C は $34.4 \mathrm{mg}$ 増加した。 口腔関連 QOL について も機能面，心理面など良好な結果となった（図 13）.
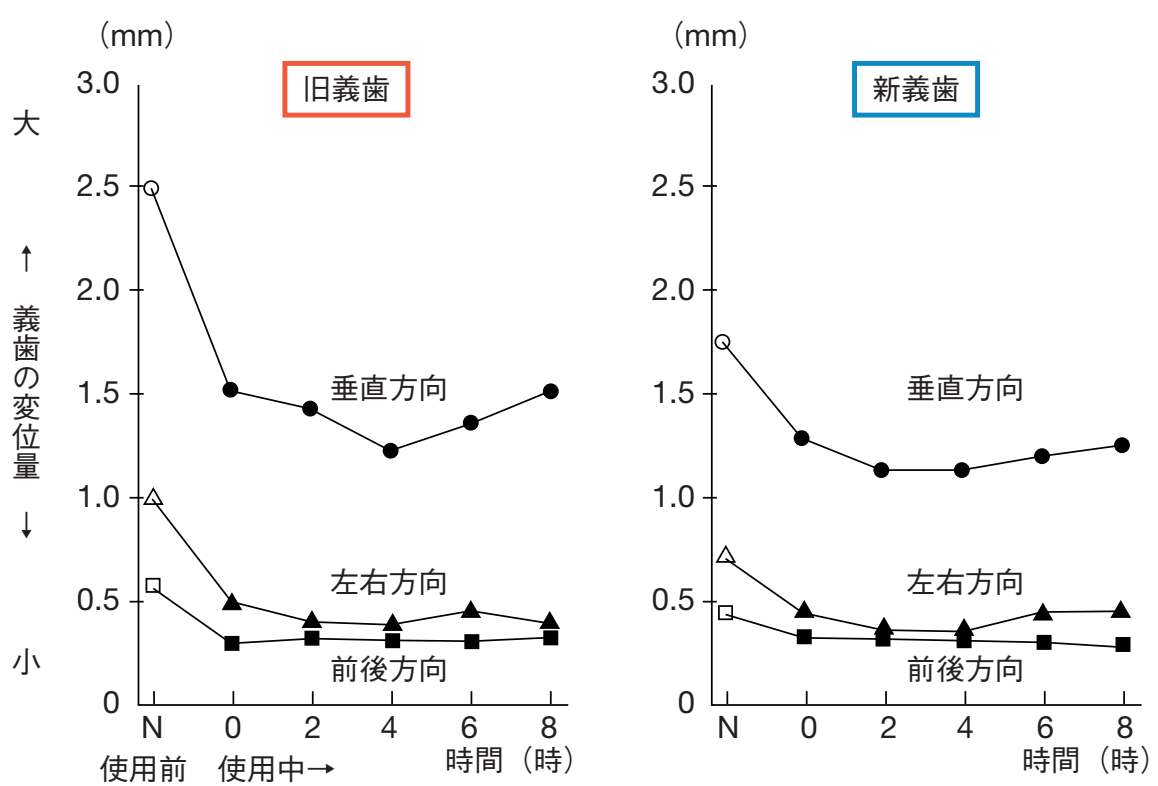

図12 クリームタイプ義歯安定剂 による上顎義歯の動摇度改善効果

（文献16より引用，一部改変） 義歯安定剤使用前後のアンズ咀嚼 時における上顎全部床義歯の垂直, 前後および側方への偏位量を経時 的に測定. 新旧義歯ともに義歯安 定剤使用により有意に偏位量が減 少した.

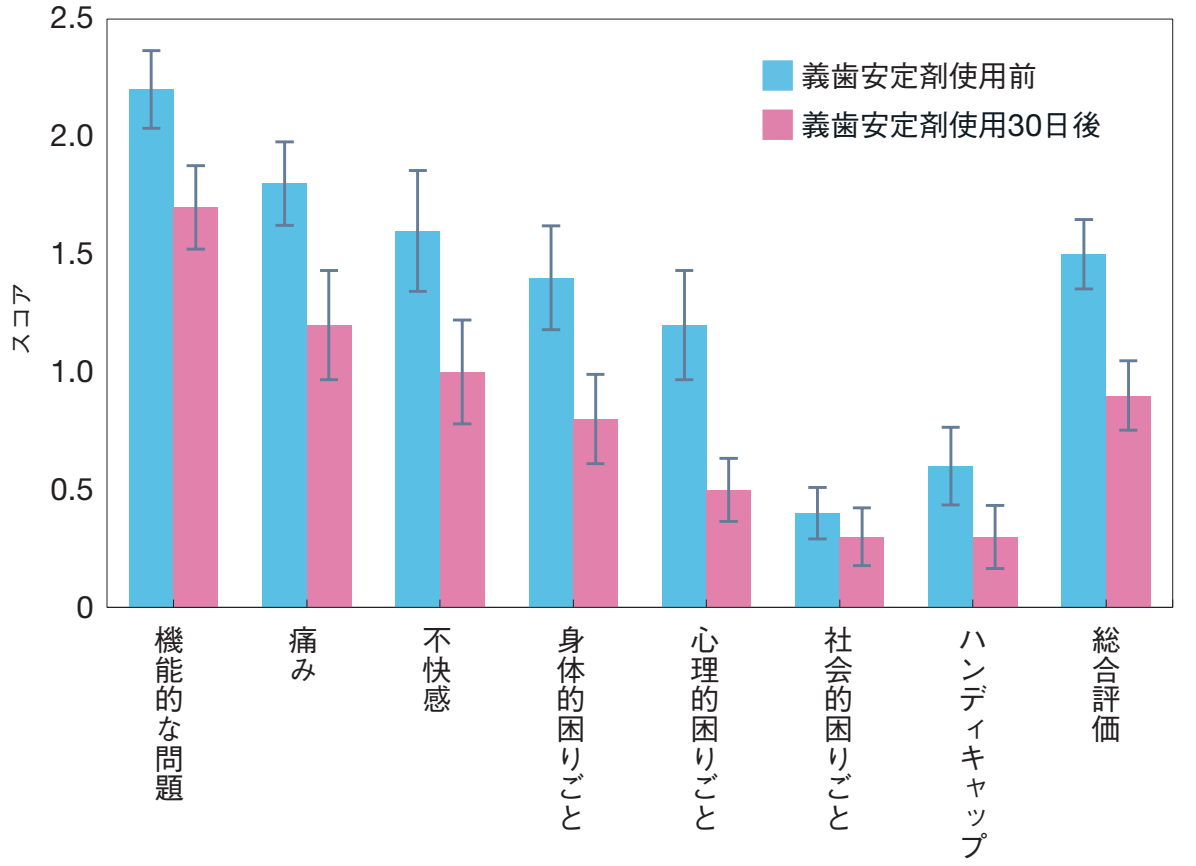

図13 クリームタイプ義歯安定剤 による口腔関連QOL向上の効果 (文献18より引用, 一部改変) 35 名の無歯顎患者(平均年齢 73.9 歳) を対象にリーフレッ 卜による簡単な食事指導を行 い,クリームタイプ義歯安定剤 (Poligrip ${ }^{\circledR}$ ) を30日間使用して もらった．義歯安定剤の使用前後 にModified OHIP Edentによる主 観的評価を行った. 
さらなる臨床研究が必要であるが, 義歯安定剤のうち クリームタイプと粉末タイプの適用症例と目的は, 現在 のところ以下のように考えられる4).

(1)新義歯完成までの期間，義歯床下粘膜との適合性 や維持力が低下した現有義歯の維持，安定性を向 上させる。

(2)適合が良好な義歯を装着していても，加齢や服用 薬などが原因で唾液の分泌量が減少し, 維持, 安 定が不良になり, 痛みを生じる症例が存在する。 このような患者に対して唾液の粘度を上昇させ, あるいはその不足を補うことにより，維持，安定 性を向上させる.

(3)適合良好な義歯を装着しているが形態の不良な顎 堤を有する症例などにおいて，維持力を向上させ ることにより咀嚼能力を向上させたり，精神的な 安心感を得ることができる。また本剤の層により 咀嚼力の口腔粘膜への刺激を軽減させることがで きる。

\section{義歯安定剤の正しい使い方と患者指導}

\section{1）定期検査}

義歯装着者への指導でもっとも重要なことは，定期的 に歯科医院に来院してもらうことである，義歯安定剤の みに頼り，リラインなど不適合義歯に対する適切な処置
が放置されないようにしなければならない.

2）推奨するタイプ

義歯安定剂が必要な症例には，使用方法などを適切に 指導したうえで，クリームタイプあるいは粉末タイプの 義歯安定殽を指示する．前述したように，クッションタ イプの義歯安定剤は粘度が高いため, 咬合を変化させた り床下粘膜との不適合を引き起こす可能性がある。 その ためクッションタイプはあまり推奨できない 1$).$

3）クリームタイプ義歯安定剂の使い方

義歯を水洗いし, 水分を拭き取る。全部床義歯の場合, 義歯床粘膜面に適当な間隔をあけ，本剂を $2 \sim 3$ 力所に それぞれ小豆程度の量を塗布する（図 14）。塗布量は計 $3 \mathrm{~cm}$ 以内, 1 日 1 回の塗布とする. 水で口腔内をすすぎ, 本剤を塗布した義歯を口腔内に装着する。そのまま 1 分 間咬合させておく，就寝時など義歯を取り外した後，口 腔内に残留した義歯安定剤はガーゼなどで拭い取る。ま た義歯に付着した義歯粘着剤は流水下で義歯用ブラシを 用い取り除く。その際ブラッシング用の義歯洗浄剤を使 用すると効果的である（図 15）。

\section{4）粉末タイプ義歯安定剂の使い方}

義歯を水洗いし，水分がある状態で適量，粉末タイプ 義歯安定剤を振り掛ける（図 16）。余分に振り掛けた場 合は，義歯を軽くたたいて振り落す。ついで本剤を塗布
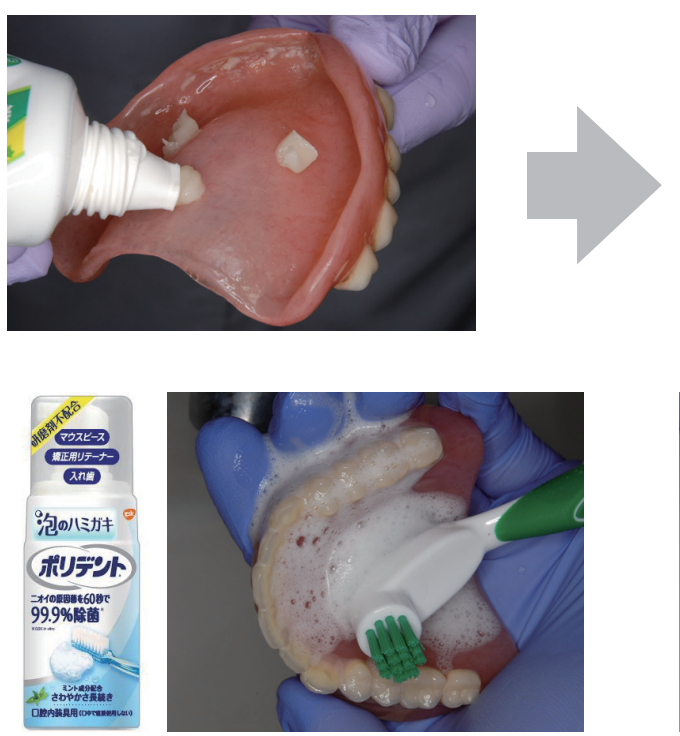

図15 ブラッシング用義歯洗浄剂を使用し た義歯の清掃

本症例は「ポリデント泡のハミガキ(グラ クソ・スミスクライン)」を使用

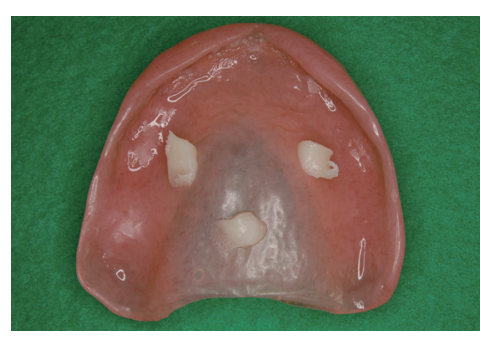

図14 クリームタイプ義歯安定 剤の使い方 全部床義歯の場合, 小豆3粒程度 を義歯床粘膜面に塗布する。
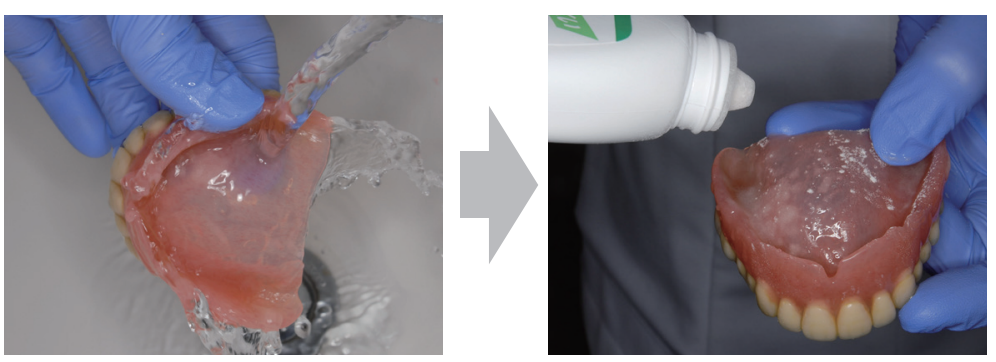

図16 粉末タイプ義歯安定剤の使い方 義歯を水で洗い, 水分を付着させる. ついで適量, 義歯床粘膜面に振り掛 ける. 
した義歯を口腔内に装着し，しばらく咬合させておく． クリームタイプと同様，義歯を取り外した後は口腔内に 残留した本剤をガーゼなどで拭い取る，義歯に付着した 義歯安定剤は流水下で義歯用ブラシを用い取り除く。な お粉末タイプは振り掛ける粉と水の量の割合により，粘 着性がかなり異なってくる，そのため粘着性を毎回一定 に保つのはむつかしいかもしれない.

\section{5）指導上の注意事項}

義歯安定剂使用に際しとくに注意すべき事項はその 使用量である。クリームタイプの場合，前述したよう に小豆 3 粒程度の量で十分で，これ以上の量が必要な 場合はリラインなどの適用と考えられる，義歯安定剤 の層は薄いほど，粘着強さは高くなる傾向であるので
（図 17）13），患者には必要最小量を塗布し，義歯をし っかりと咬合するよう指示することが重要である.

クリームタイプや粉末タイプの義歯安定剤は粘膜への 付着性が高いため, 多量に塗布されていると診療に支障 をきたす（図 18）。たとえば印象採得時に粘膜に付着し た義歯安定剤を完全に除去するのに，かなりの時間を要 することになる。このような経験をされた先生方は多く いらっしゃるのではないかと思う. 義歯の印象採得を行 う診療日は, 義歯安定剤を塗布せずに来院するよう指示 する必要がある。また本剤が多量に塗布されていると, 口腔内がべたつき，患者自身，感覚的にも快適ではない． なお部分床義歯の場合, 使用量が多く層が厚くなると, クラスプが浮き上がり逆に維持力低下をきたす。

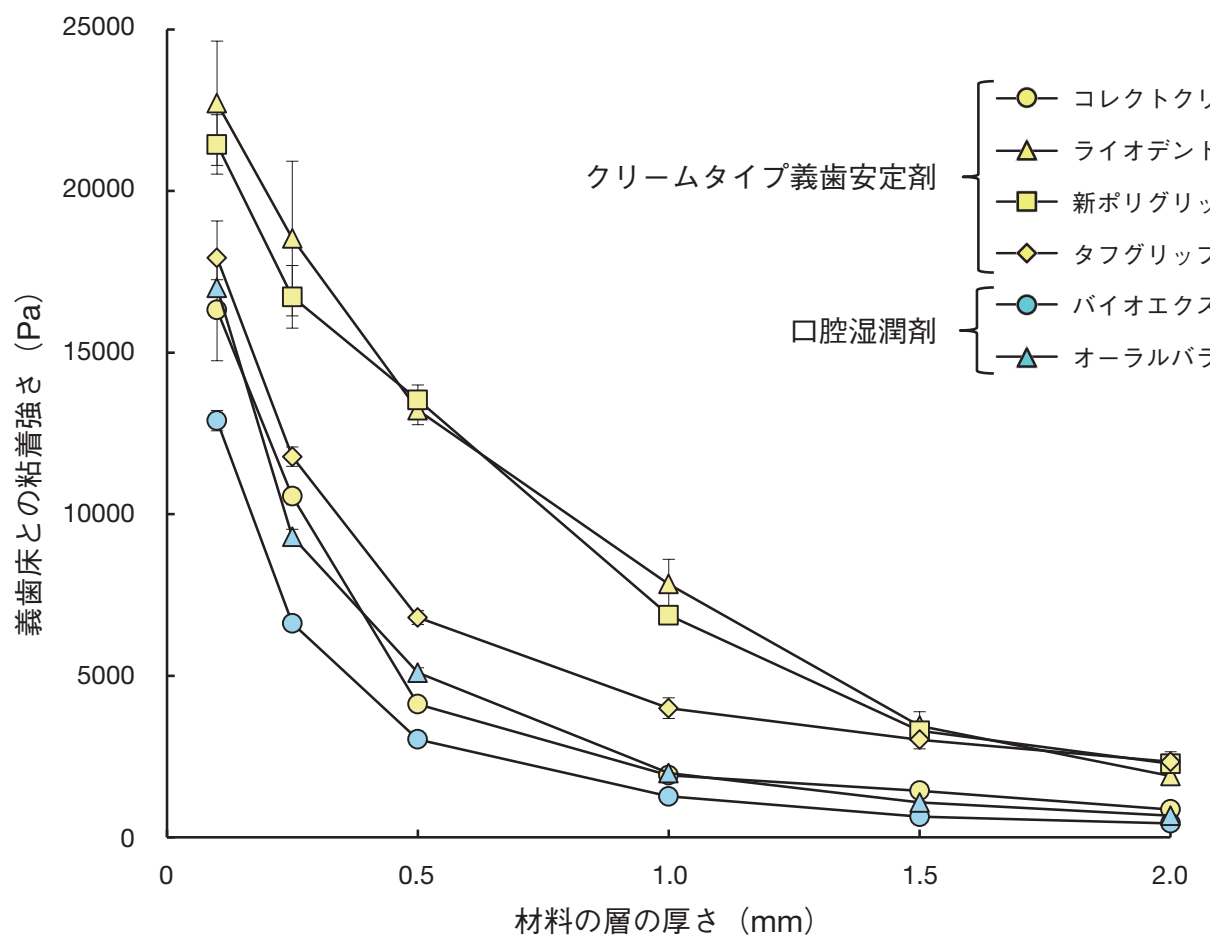

図17 クリームタイプ義歯安定 剤および口腔湿潤剤の層の厚さ と義歯床との粘着強さとの関係 (文献13よりデーターを引用し， グラフを作成)

材料の層の厚さが薄いほど, つ まり量が少ないほど義歯床との 維持力が強くなることがわかる.

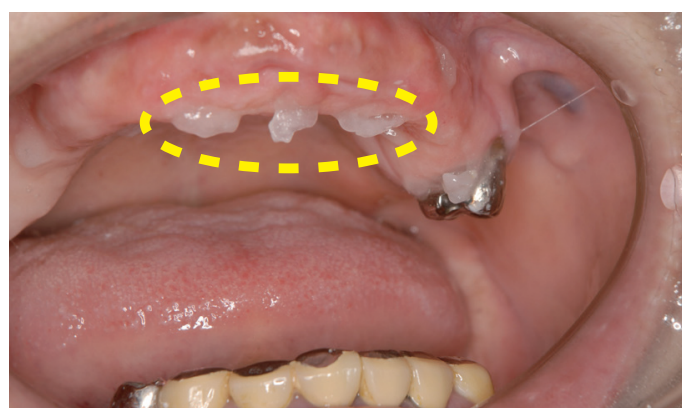

164
図18 口腔粘膜に多量に付着したクリームタイプ義歯安定剂 使用量が多すぎると粘膜からの除去に時間を要する. 適切な使用量を 守ることが重要である. 
おわりに

義歯安定剤はドラッグストアで義歯使用者が容易に購 入でき，それゆえ歯科医師が十分に管理を行うことがむ つかしい，本剤は義歯管理や補経歯科治療に有用な補助 的材料であり，その効果を十分に発揮させ，誤使用によ る弊害を防ぐためには，歯科医師が正しい知識をもち，

参考文献

1）古屋良一, 曾田雅啓, 嶋倉道郎ほか: 義歯安定剂 (材)に関 する現状分析と見解. 補経誌, 44: 565-569, 2000.

2）厚生労働省平成28年歯科疾患実態調查. http://www mhlw.go.jp/toukei/list/62-28.html

3）村田比呂司：義歯安定剂を使用している患者が来院した ら……義歯安定剂の功罪一. 補綴臨床, 46: 314-327, 2013.

4）村田比呂司, 山田真緒, 岡㟝ひとみ: どう付き合う? 義歯安定 剂.ザ•クインテッセンス, 36(3): 42-59, 2017.

5） JIS T6525-1: 2013, JIS T6525-2: 2013. 義歯床安定用こ (糊) 材 - 第1部: 粘着型義歯床安定用こ(糊) 材, 義歯床安 定用こ(糊)材一第 2 部: 密着型義歯床安定用こ(糊) 材

6）浜田泰三, 村田比吕司, 夕田貞之, ほか: 義歯安定剤: デンタ ルダイヤモンド社(東京), 2003.

7）高橋英和：義歯安定剂の種類と性質. 補綴誌, 47: 474-483, 2003.

8) Slaughter A, Katz RV, Grasso JE: Professional attitudes toward denture adhesives: A Delphi Technique survey of academic prosthodontists. J Prosthet Dent, 82: 80-89, 1999.

9）守澤正幸: 義歯粘着剤に対する補綴専門医の考え方 (JPD の要約).ザ・クインテッセンス, 19(3): 119-566, 2000.

10) Felton D, Cooper L, Duqum I, et al.: Evidence-based guidelines for the care and maintenance of complete
患者や場合によってはその介護者などに正しい使い方を 教育, 啓発していくことが重要である。本稿が先生方の 日常臨床や患者指導にお役に立てれば幸いである。

\section{謝辞}

本総説執筆の機会を与えていただいた黒岩昭弘 編集委員会委員 長ならびに関係者の方々に感謝申し上げます。 dentures: A publication of the American College of Prosthodontists. J Am Dent Assoc, 142: 1S-20S, 2011.

11) ISO 10873: 2010. Dentistry - Denture adhesives.

12）牧平清超, 二川浩樹, 西村春樹ほか: 義歯安定剂 (材) 溶 出液がヒト線維芽細胞に与える影響. 補綴誌, 45: 403-411, 2001.

13) Kano H, Kurogi $T$, Shimizu $T$, et al:: Viscosity and adhesion strength of cream-type denture adhesives and mouth moisturizers. Dent Mater J, 31: 960-968, 2012.

14) Sipahi C, Beyzadeoglu M, Demirtas S, et al.: Effect of different mucosal and acrylic resin surface treatments in a denture retention model for patients with radiotherapyinduced xerostomia. Int J Prosthodont, 20: 405-408, 2007.

15) Murata H, Hong G, Yamakado C, et al.: Dynamic viscoelastic properties, water absorption, and solubility of home reliners. Dent Mater J, 29: 554-561, 2010.

16) Grasso JE, Rendell J, Gay T: Effect of denture adhesive on the retention and stability of maxillary dentures. J Prosthet Dent, 72: 399-405, 1994.

17）早川 䉷：長生きする入れ歯 科学的根拠に基づく知識と治 療法(ブルーバックス). 講談社(東京), 2007.

18) Bartlett DW, Maggio B, Targett $\mathrm{D}$, et al.: A preliminary investigation into the use of denture adhesives combined with dietary advice to improve diets in complete denture wearers. J Dent, 41: 143-147, 2013. 